\title{
Yo despierta, ella dormida. Sor Juana Inés y Juan Rulfo o la nueva condición poética latinoamericana ${ }^{* *}$
}

\author{
I awake, she slept. Sor Juana Ines and Juan Rulfo \\ or the new Latin American poetic condition
}

\author{
Eu acordada, ela adormecida. Soror Juana Inés e Juan Rulfo \\ ou a nova condição poética latino-americana
}

\footnotetext{
* Tiene estudios de literatura y teatro. Es especialista en prácticas audiovisuales y magíster en literaturas colombiana y latinoamericana. Ha publicado en El quinteto de Versalles, en la compilación bilingüe Cali-grafías, la ciudad literaria y en las antologías de los concursos Carlos Castro Saavedra, Alejo Carpentier, Ciencia-ficción del Instituto Distrital de Cultura, y A quien corresponda (México, 2001), así como en las revistas Número, Poligramas, Deriva, El Arte, Papel Escena, y en diversos diarios del país. Ha recibido galardones nacionales e internacionales entre los que figuran los concursos Alejo Carpentier, Carlos Castro Saavedra, Germán Vargas, el Concurso de ciencia ficción del Instituto Distrital de Cultura y Turismo, la Beca de Creación Colcultura y el Premio A quien corresponda, México. Fue miembro del TEC y fundador y director del grupo de teatro Barco Ebrio. Actualmente, es el Jefe del Departamento de Lenguaje de la Universidad Icesi, donde combina docencia e investigación en los campos de la cultura y la educación. En el Doctorado de Literatura de la UTP realiza su investigación en la línea de Literatura Latinoamericana. Correo electrónico: hdelgado@icesi.edu.co

** Este artículo es el resultado de una investigación en el marco del Seminario Teoría y Crítica Literaria III, dentro de la línea de investigación en Literatura Latinoamericana del Doctorado de Literatura de la Universidad tecnológica de Pereira (UTP) Artículo de investigación recibido el 10/09/2015 y aceptado el 29/11/2015
} 


\section{Cómo citar}

Delgado, H. (2015). Yo despierta, ella dormida. Sor Juana Inés y Juan Rulfo o la nueva condición poética latinoamericana. Revista CS, no. 17, pp. 39-62. Cali, Colombia:

Facultad de Derecho y Ciencias Sociales, Universidad Icesi.

DOI: http://dx.doi.org/10.18046/recs.i17.2072 


\section{Resumen}

Abstract

Resumo

El artículo examina la forma como Sor Juana Inés de la Cruz y Juan Rulfo, en diálogo con la tradición literaria -especialmente con la obra de Dante, el gongorismo y la tradición moderna- construyen una condición poética latinoamericana. Para ello estudia el largo ascenso onírico de Sor Juana en Primero sueño, y la historia de Susana San Juan en Pedro Páramo, la novela de Rulfo. Para el análisis, acude a los conceptos de resistencia al padecer y de signos de la trascendencia provistos por María Zambrano en sus reflexiones sobre la condición esencial de lo humano. Sor Juana y Susana San Juan ofrecen esa resistencia: Sor Juana, mediante el viaje del conocimiento, la soberanía del cuerpo, la exposición de la precariedad de la vida y la metáfora del ascenso; Susana, mediante la caída, la locura y el erotismo. Finalmente, interpreta en ambos personajes la apropiación de signos de la trascendencia: la revaloración del instante, de los sueños y la creación-destrucción de lo divino. Concluye mostrando cómo Sor Juana recoge el impulso que arranca en Europa con Montaigne, Bacon, el Renacimiento y el Siglo de Oro, y propone trasformaciones significativas que permiten hablar de una condición poética distinta. Y cómo Rulfo, arrancando de la condición mítico-religiosa americana, del no-lugar, de la indefinición ontológica, se detiene en la imagen del Purgatorio: muestra allí la conciencia luminosa, el erotismo desatado y la locura sacralizada de Susana como un aligeramiento, una posibilidad de fuga y de redención humana de la condena.

\section{PALABRAS CLAVE:}

Condición poética | condición humana | pensamiento poético | razón poética | poesía | metáfora

The article examines how Sor Juana Ines de la Cruz and Juan Rulfo, in dialogue with the literary tradition -especially with the works of Dante, Gongorism and the modern tradition- build a Latin American poetic condition. To that end, it studies the long dream of Sor Juana rise, in First Dream; and Susana San Juan history, in Pedro Páramo. For the analysis, it goes to the concepts of resistance to suffering and the signals to transcendence provided by Maria Zambrano in his reflections on the essential condition of the human. It explains how Sor Juana and Susana San Juan offer such resistance: Sor Juana through the journey of knowledge, the sovereignty of the body, exposing the precariousness of life and the metaphor of the ascent; Susana, through the fall, madness and eroticism. Finally, it plays, in both 
characters, the appropriation of the signs of transcendence: the revaluation of the moment, of dreams and the creation-destruction of the divine. It concludes by showing how Sor Juana takes the momentum in Europe with Montaigne, Bacon, the Renaissance and the Golden Age and proposes significant transformations that allow speaking of a different poetic condition. And how Rulfo, tearing off from American mythic-religious condition, of the non-place, of the ontological undefinition, stops at the image of Purgatory: showing there the luminous consciousness, the eroticism unleashed and the madness sacralized of Susana as a relief, a possibility of leakage and human redemption of the sentence.

\section{KEYWORDS:}

Poetic condition | human condition | poetic thoughts | poetic reason | poetry | metaphor

O artigo examina a forma como Soror Juana Inés de La Cruz e Juan Rulfo, em diálogo com a tradição literária - especialmente com a obra de Dante, o gongorismo e a tradição moderna- constroem uma condição poética latino-americana. Para isso, estuda o longo Ascenso onírico de Soror Juana, em Primeiro sonho; e a história de Susana San Juan, em Pedro Páramo. Para a análise, recorre aos conceitos de resistência ao padecer e de sinais da transcendência proporcionados por Maria Zambrano em suas reflexões sobre a condição essencial do que é humano. Expõe como Soror Juana e Susana San Juan oferecem essa resistência: Soror Juana, mediante a viagem do conhecimento, a soberania do corpo, a exposição da precariedade da vida e a metáfora do Ascenso; Susana, por meio da queda, a loucura e o erotismo. Finalmente, interpreta em ambos os personagens a apropriação de sinais da transcendência: a revalorização do instante, dos sonhos e a criação-destruição do que é divino. Conclui mostrando como Soror Juana recolhe o impulso que começa na Europa com Montaigne, Bacon, o Renascimento e o Século de Ouro e propõe transformações significativas que permitem falar de uma condição poética diferente. E como Rulfo, partindo da condição mítico-religiosa americana, do não-lugar, da indefinição ontológica, se detém na imagem do Purgatório: mostra ali a consciência luminosa, o erotismo desatado e a loucura sacralizada de Susana como um alívio, uma possibilidade de fuga e de redenção humana da condenação.

\section{PALAVRAS CHAVES:}

Condição poética | condição humana | pensamento poético | razão poética | poesia, metáfora 


\section{Introducción}

La más antigua, la más vívida imagen de la condición poética que haya tejido el hombre está en aquella metáfora bíblica: «Ya vieron tus ojos mis obras, siendo escritas todas en tu libro» (Salmos 139: 16 N. Colunga). Todo creador aspira de forma secreta a un lugar sobrenatural en el que le sea dado ver todas las cosas que fueron y serán. Ver el libro de Dios. La singular metáfora de un hombre que en pos de una mujer accede al mundo sobrenatural donde le son deparadas las visiones del Infierno, del Purgatorio y del Paraíso; el caldero de espejos líquidos que las Parcas le presentan a Macbeth, donde este ve las generaciones de reyes que lo sucederán; el lúcido punto que contiene todos los puntos, oculto en un sótano de Buenos Aires, donde un hombre ve cara a cara el universo... Entre cualquiera de las metáforas de Dante, Shakespeare o Borges comprobamos la misma idea: el poeta anda a la búsqueda de algo que dé sentido superior a la existencia. Más allá de las ruinas del amor, del poder, de la ceguera o del espíritu -más allá de nuestra condición humana, diremos-, el poeta ha trazado la posibilidad de la conquista de una condición superior: la condición poética.

Allí están, para probarlo, Cervantes, Milton, Bacon, Goethe, Voltaire, Beckford, Swedenborg, Blake, Poe, Kafka y Borges. Si la condición poética cristaliza en la creación o postulación de otro mundo que cifre el universo, las dichas y los afanes del hombre, las cosas que fueron y serán, y una realidad inmediata tratada de manera intensa y memorable, hemos de admitir a Dante como símbolo del creador que levanta una metáfora plena de esa condición, una "lámina de ámbito universal”, como la llamó Borges (1982).

En Latinoamérica, Borges alcanza la condición poética mediante un gesto distinto que tiene antecedentes en Poe y Kafka: obra en lo mínimo, por demolición cuidadosa de las partes de la metáfora, o para decirlo de otra manera, mediante la deconstrucción de la metáfora abordándola como si se tratara no de una totalidad sino de una gama de problemas aislados que remiten secretamente al todo, en Nueve ensayos dantescos, o de una metáfora puntual, incisiva, inserta en la metáfora total, que aspira a anularla desde adentro, en $E l A l e p h^{1}$. Este último procedimiento le ganará fama a la poética de Borges como totalmente nueva y poderosa: su gesto perfecciona los procedimientos de sus maestros Poe y Kafka; y en tanto es personalísimo, irradia y contamina el mundo y la literatura. Esto es, se torna condición.

Sin embargo, Borges no es el único caso latinoamericano. Tampoco es, en relación con la metáfora dantesca, el caso inaugural ni el superior. Latinoamérica acoge a dos autores separados entre sí por casi trescientos años, cuyos opúsculos corresponden, respectivamente, al momento inaugural y al cimero de ese gesto: Sor Juana Inés de la 
Cruz, con Primero sueño, y Juan Rulfo, con Pedro Páramo. El diálogo ${ }^{2}$ de ambas obras con la metáfora dantesca es claro: el de Primero sueño con el ámbito celeste; el de Pedro Páramo, con el infernal. El de Sor Juana, con el ascenso; el de Rulfo, con la caída. En lo que sigue, nos dedicaremos a examinar -y tal vez sostener- cómo estos dos autores reconstruyen la metáfora plena y aportan, como lo ha hecho Borges, al surgimiento de una nueva condición poética con origen en Latinoamérica.

Numerosas poéticas tejidas a lo largo del tiempo hacen preciso rastrear y sintetizar el concepto de condición poética que ha de servir a nuestro examen. En su búsqueda de dotar a la existencia de un sentido superior, todo hombre choca con su condición humana, moneda con que paga el ser animal y haberse rediseñado como hombre que aspira a la divinidad. "Seréis como dioses", dice Juan. El poeta, por su capacidad para padecer la condición humana y por su impulso para trascenderla, enfrenta al límite. Quiere conjugar vida y muerte, razón e intuición, instante y eternidad, materia y espíritu; quiere sacar de sí al ángel y a la bestia y elevarlos a otra condición. El poeta nos lleva a estar, a sentir, a pensar, a ver y a transformar el mundo bajo un modo poético. Para el mundo es necesaria la temeridad de su empresa. Esa nueva condición, como se observa, es más que un estado, un sentimiento, una razón o una acción. Un estado como el rapto poético, un sentimiento como la efusión poética, la razón poética como conciliación del logos racional y del intuitivo, la mirada y el acto poéticos no son suficientes. La nueva condición es el resultado de todo ello, que sólo puede darse entre el poeta y el lector en un encuentro singular en el que juega papel central la experiencia.

Barth habla de facultades del poeta superior: intelecto profundo, gran visión humana, poder poético, y dominio consumado de sus medios (Barth, 1967); conceptos que treinta años después, Harold Bloom, sin reconocer la paternidad de Barth, resumirá en: agudeza cognitiva, energía lingüística y poder de invención (Bloom, 2001). Por su parte, Jay ha estudiado amplia y lucidamente la posibilidad de la transmisión de la experiencia poética (Jay, 2009). En Sor Juana y Rulfo encontramos no solo las facultades de los poetas superiores sino la capacidad de concentrar y transmitir la experiencia en contadas imágenes y contados personajes. En ese sentido, obran como Borges. Dos episodios de sus obras nos ocupan: del largo ascenso onírico de Sor Juana, el poder transformador y metafórico del último trayecto de Primero sueño; de la novela de Rulfo, la historia de Susana San Juan, que se extiende como un hilo de Ariadna por los recintos de muertos 
de Comala. Pero sus personajes no son menos. Todo lo contrario: si hemos señalado la especial condición poética de estas dos obras, se debe precisamente a las características que encarnan esa mujer-voz, la hablante poética de Primero sueño, y Susana San Juan, en Pedro Páramo. Dos mujeres poetizadas; dos experiencias transformadoras. Sus episodios son las perlas irregulares engastada en la masa barroca del texto, cuyo precioso brillo ha sido capturado mediante dos sintagmas verbales: yo despierta; ella dormida .

¿Cómo proceder, pues, a desentrañar la condición poética de estos textos? Una tercera mujer nos presta su concurso. María Zambrano habla de la manera como se expresa la condición esencial: en primer lugar, en el padecer del ser humano; y luego, en su lucha contra el tiempo, en los signos de la trascendencia: el valor del instante, de los sueños y de la creación-destrucción de lo divino (Bravo, 1998). Intentaremos, pues, examinar en Primero Sueño y en la historia de Susana San Juan la resistencia al padecimiento y los signos de la trascendencia.

\section{II \\ Padecimiento y resistencia}

La íntima herida de la mujer separada de la trascendencia se experimenta como fragilidad, como sufrimiento. Donde otros autores pudieran ver en la mujer una oportunidad del arrebato, de ayes lastimeros o patetismo lánguido, acaso irracional, Sor Juana y Rulfo intuyen mujeres de lucidez serena o desgarrada. En ambas asombra la decisión por la soledad: el retiro, en una; el aislamiento, en la otra. En Sor Juana, el heroismo de la luz; en Susana, el heroismo de la sombra. En Primero sueño y en Pedro Páramo, la mujer pronuncia la pesadez del mundo que arrebata al cuerpo su posibilidad de elevarse, de trascender y de ser libre.

Para responder al dolor, Sor Juana plantea el viaje del conocimiento, la soberanía del cuerpo, la exposición de la precariedad de la vida, y la metáfora del ascenso. Nos detenemos fugazmente en la primera de ellas, el viaje, tema harto trabajado por la crítica. Paz (1982) ha insistido en el viaje de Sor Juana no como un arrebato místico sino como un viaje de conocimiento. Equipara, en ello, a la monja jerónima con Mallarmé. Pero añade una inflexión aguda: más que de conocer, su viaje plantea el ansia de saber. En ese sentido, Sor Juana recoge el impulso individualista y la revaloración de la experiencia interior como posibilidad de dar luz a una verdad sobre el mundo -impulso que en Europa expresan cimas como Montaigne y Bacon, precipita el Renacimiento y el Siglo de Oro-, y que da en sus manos un vuelco revelador. Paz hace despuntar así una de las virtudes de la nueva condición poética de Sor Juana.

Unido al viaje, el poema ahonda en la naturaleza del cuerpo, descrito por sus propiedades físicas y espirituales. Un cuerpo hecho de músculos y partes: "lánguidos 
miembros, sosegados huesos" donde el pulmón es "imán del viento" y el estómago "científica oficina"; un cuerpo poblado de humores corporales: "húmedos, mas no tan claros los vapores /de los atemperados cuatro humores"; de facultades mentales: "los simulacros que la estimativa /dio a la imaginativa / [...] la memoria que, oficiosa, /gravó tenaz y guarda cuidadosa /sino que daban a la fantasía /lugar de que formase / imágenes diversas"; habitado, además, por un alma ansiosa: "La cual, en tanto, toda convertida /a su inmaterial ser y esencia bella, /aquella contemplaba, /participada de alto ser centella". Un cuerpo que, elevado a forma etérea, se abisma en las operaciones intelectuales superiores: "ciencia a formar de los universales, /reparando advertido, / con el arte el defecto /de no poder con un intuitivo /conocer acto todo lo criado, /sino que haciendo escala de en concepto /en otro va ascendiendo grado a grado, /y el de comprehender orden relativo /sigue necesitado /de él-del entendimiento..."; y que al final, después de haber retrocedido ante la contemplación de lo divino, se concibe lleno de pasión y deseo sublimes:

\author{
¿Porqué? Quizá porque más venturosa \\ que todas, encumbrada, \\ a merced de amorosa \\ unión sería. ¡Oh aunque repetida, \\ nunca bastante bien sabida \\ merced! pues, ignorada, \\ en lo poco apreciada \\ parece o en lo mal correspondida. (696-703).
}

El viaje descubre un segundo propósito aunado al ansia de saber: la unión amorosa. ¿Se trata de la unión espiritual o de la material? ¿Del restañamiento de la condición humana por la fusión de lo humano y lo divino, de la razón y la intuición, del instante y la eternidad? De todas, sin duda. Pero especialmente de todas ellas bajo la forma del deseo corporal. Harto se ha discutido el doble registro característico del barroco. Tómese como ejemplo el fragmento comprendido por los versos 730 a 780 , al que llamaremos episodio de la Flor Carnal, que empieza con "quien de la breve flor aún no sabía...”, y termina en: “...la empresa /de investigar a la Naturaleza?”. El pasaje admite la doble lectura: como ejemplo del imposible conocimiento total del universo en tanto no podemos dar cuenta siquiera de una flor; o como imagen del terror que embota el conocimiento ante una flor abruptamente carnal, "dulce herida de la cipria diosa (...) ejemplo profano /de industria feminil que el más activo /veneno hace dos veces ser nocivo /en el velo aparente /de la que finge tez respladeciente". ¿Se necesita más elocuencia? El gesto de Sor Juana, en el vaivén de lo trascendente a lo contingente, se adensa en el paso de lo filosófico a lo poético, a lo erótico y de aquí a lo político. La presencia del poder eclesial, que se concreta en el control del cuerpo, del pensamiento y del deseo, llevan a Sor Juana 
a la resistencia. En esa medida, el suyo es un gesto político, como lo es también la aspiración al conocimiento total por oposición a la idea de sujeción del conocimiento a la única vía permitida, la religiosa, y asumiendo la posibilidad del conocimiento a través de la ciencia y de la experiencia personal.

Un juego semejante puede constatarse en la tercera operación, la de exponer la fragilidad de la vida. Sor Juana escoge como símbolos de tal debilidad el sueño de cada noche y sus signos consubstanciales: el cansancio, el silencio, el reposo, el abandono, la pérdida de conciencia, la falta de luz. Elige imágenes que revelan:

a. La fragilidad como equilibrio precario: "El viento sosegado, el can dormido, / éste yace, aquél quedo /los átomos no mueve, /con el susurro hacer temiendo leve, /aunque poco, sacrílego rüido, /violador del silencio sosegado" (80-85); para no romper el silencio, el viento parece quedarse dormido; el águila, en el duermevela, aprieta en su pata una pequeña piedra que, de dormirse, cae y la despierta.

b. La precariedad como contradicción central de la vida: “...el cuerpo siendo, en sosegada calma, /un cadáver con alma, /muerto a la vida y a la muerte vivo” (201-203). Para referirse al poder de la Naturaleza habla de "el fiel infiel con que gobierna / la aparatosa máquina del mundo" (164-165); y para hablar de los sentidos: "quedaron los sentidos /del que ejercicio tienen ordinario/ trabajo en fin, pero trabajo amado /si hay amable trabajo-, /si privados no, al menos suspendidos, /y cediendo al retrato del contrario/de la vida..". (168-174).

c. La fragilidad como peligro: "El de sus mismos perros acosado, /monarca en otro tiempo esclarecido,/tímido ya venado,/con vigilante oído,/del sosegado ambiente, /al menor perceptible movimiento/que los átomos muda,/la oreja alterna aguda/y el leve rumor siente /que aun le altera dormido" (113-122). Acteón, rey convertido en venado ante sus propios perros, al llegar el sueño se ve obligado a vigilar. Busca el sueño para descansar, pero en él no puede descansar porque la muerte acecha en sus canes custodios.

d. Y, finalmente, la fragilidad como experiencia de derrota, como "llorado ensayo (...) contra el Sol, digo, cuerpo luminoso, /cuyos rayos castigo son fogoso, /que fuerzas desiguales / despreciando, castigan rayo a rayo/el confiado, antes atrevido/y ya llorado ensayo / necia experiencia que costosa tanto / fué, que Ícaro ya, su propio llanto /lo anegó enternecido), /como el entendimiento, aquí vencido...” (460-469).

Toda esta operación tiene como propósito derivar de ella una segunda lección: por medio del abandono, el silencio y la vulnerabilidad, la mujer ha podido remontarse a otro estado. El sueño deja, pues, de ser la actividad nocturna para transformarse en condición y potencia del espíritu. Como oportunidad a la cuarta operación, el ascenso.

Camino del cielo, remontando las esferas sublunares, Sor Juana viaja sola, guiada por razón e intuición o, dicho a la manera de la psicología medieval, por los cinco sentidos 
externos y las cuatro facultades internas: estimativa o cogitativa, imaginativa, sentido común y memoria; a las que Avicena añadirá fantasía (Arroyo: 2001). Su ascenso reposa en la imagen de la pirámide mental ${ }^{3}$, recorre los cuerpos celestes y escala todos los grados del conocimiento humano (mineral, vegetal, animal, hombre, ángel y Dios) hasta divisar la perfección divina: "fin de Sus obras, Círculo que cierra /la Esfera con la tierra, /última perfección de lo crïado /y último de su Eterno Autor agrado, /en quien con satisfecha complacencia /Su inmensa descansó magnificencia...” (671-676).

Insuficientes, intuición y razón no alcanzan su propósito y el alma retrocede, abrumada, ante la visión cegadora de Dios. El procedimiento de Sor Juana es perfectamente extensible al barroco: la búsqueda de la luz a través de la oscuridad. En abierta resistencia a la poesía del siglo XVII, Sor Juana construye su oscuridad apelando a la forma poética y al barroquismo intelectual. De ese modo plantea un gesto de libertad a las exigencias de racionalización de su tiempo. Su resultado, lo sabemos, es el ensayo, el llorado ensayo. La crítica, más atenta a la forma textual de la silva, elegida por Sor Juana como forma adecuada a los desvelos barrocos, ha descuidado la luz que arroja la palabra ensayo en el poema. Se trata, en efecto, de una silva con tono ensayístico en sus dos terceras partes que, siguiendo las fases de la luna, se resuelve en rapto poético al cabo del tercio final. De esa distinción tonal depende uno de los mayores logros del poema, cuya significación reservamos para el cierre de estas páginas.

En Pedro Páramo, Susana San Juan expresa un padecimiento sordo, transverberante. De la Susana abierta y extrovertida del comienzo pasamos a la mujer aislada, desgarrada por la memoria y los sueños del final. No se trata de un dolor incomunicable sino de la determinación de Susana de clausurar los accesos al mundo: el espacio, la voz y el sexo. Clausura del espacio, por cuanto huye de la tierra para terminar soterrada en la mina, en la casa, en la tumba; de la voz, puesto que dueña de una palabra elocuente y poética, enmudece poco a poco, decidida a no expresar sus tormentos; y del sexo, al acabar acorralada por el apetito sexual: desea a Florencio, este ha muerto y, en consecuencia, Susana termina sus días consumiéndose, con un gesto interesantísimo ligado al símbolo urobórico del animal que devora su propio vientre.

En este sentido, Susana arrastra con la doble maldición: la de negar a su madre, la de negarse a ser madre. ¿Castidad, infertilidad? Creemos ver allí el origen de su dolor. Ni Pedro ni Florencio ni Bartolomé obtendrán de Susana el hijo que asegure la estabilidad del poder, del amor o de la familia. Como Comala, el vientre de Susana acusa la sequedad del desierto. Pedro ha intuido su origen como algo poderoso, con raíces en el sueño, en lo inalcanzable. Pero es Jacinta quien descubre la relación del dolor con la 
muerte: “...no se queja de nada; pero dicen que los muertos ya no se quejan. La señora está perdida para todos". (131).

Susana responde al padecimiento mediante la caída, la locura y el erotismo. En oposición al elevamiento intelectual de Sor Juana, guiado por la intuición, la caída en Susana obedece a una decisión lúcida, grave, ligada simbólicamente al círculo, al pecado, al descenso. Pedro Páramo es su detonador. “¿De manera que estás dispuesta a acostarte con él?", le pregunta Bartolomé a Susana. Ella sabe que Pedro es la pura maldad y, no obstante, responde: "Sí, Bartolomé” (101). Intuye que de ese modo se condena, y que la condena será eterna.

Círculo, pecado y descenso son formas de la eternidad de la caída. El círculo mayor es el tiempo. El triple éxtasis temporal es resumido por Susana en un pasado evocado como paraíso, en la postulación de un infierno al que se dirige sin remedio, y en el intenso e instantáneo purgatorio del presente. Noche, luz mortecina, cortinas cerradas, sombras, ruidos, viento y humedad constituyen la escenografía de este purgatorio. Una lluvia incesante se filtra a lo largo de la historia de Susana, como un segundo hilo -al primero, de estirpe ariádnica, nos referiremos en breve- que comunica circularidad y peso a la sombra. No es vana la alusión al agua, hay un agua del pasado que acompaña a Susana en sus sueños: el mar cálido donde ella y Florencio se bañaban desnudos; al que ella volvía y vuelve siempre. La imagen del retorno y del círculo es continua: junto al tiempo y al mar están la luna, la mina, el agujero del monte donde vivió con Bartolomé, la Media Luna, la luz pendular y parpadeante, el movimiento de la soga que ciñe la cintura de Susana niña en el socavón de muertos, el flujo continuo de la lluvia, la noria cuyas poleas desvelan a la enferma, y el símbolo del vientre como uróboros.

Esa imagen del retorno y del círculo que liga tiempo, cuerpo y naturaleza, tiene relación con otro círculo de orden simbólico. En diálogo con Justina, Susana encadena tres frases de agudísimo sentido: “¿Verdad que la noche está llena de pecados, Justina?”; “广Y qué crees que es la vida, Justina, sino un pecado? ¿No oyes? ¿No oyes cómo rechina la tierra?" (130). La analogía noche vida y vida pecado ha sido construida para llevarnos a una mayor: incapaz de soportar el peso de tanto pecado, la tierra rechina. La metáfora, figura circular por excelencia, es empleada para dibujar la idea de una esfera espantosa en la que Susana ha sido sepultada.

La caída, finalmente, está asociada al descenso. Rulfo la representa en la escena de la niña bajando al socavón. Como Ulises, Orfeo o el Quijote, ella visita el mundo de los muertos. Con una diferencia: Susana acude físicamente la primera vez, pero, luego, volverá una y otra vez en sus sueños, y con su decisión condena parejamente a Pedro Páramo y a Comala. Volvamos a la escena:

Estaba colgada de aquella soga que le lastimaba la cintura, que le sangraba sus manos; pero que no quería soltar: era como el único hilo que la sostenía al mundo de afuera (108). 
Nuevamente la presencia del hilo, tan fuerte en Rulfo. El viaje al inframundo es una muestra de la filiación ariádnica de Susana. Baja la primera vez en busca de tesoros ajenos. Más adelante, guida por el amor y la locura, vuelve en sueños a encontrarse con Florencio muerto. Abajo, se moverá al principio con terror, luego con solvencia; algunas veces con felicidad, extasiada en sus recuerdos. Arriba, de modo inverso al mito, aguarda el Minotauro.

¿Pero cuál era el mundo de Susana San Juan? Ésa fue una de las cosas que Pedro Páramo nunca llegó a saber" (114).

Pedro se quedará siempre afuera. Condenado a la soledad, a no habitar el mundo de Susana ni a poseer su corazón, el Minotauro se extingue finalmente: seco, como un montón de piedras que no son otras que las piedras del laberinto que ella teje para él allá arriba, en la realidad.

Hablamos de una segunda forma del padecimiento: la locura. Temprano, ante la pregunta de su padre sobre si está loca, Susana afirma: "Claro que sí, Bartolomé. ¿No lo sabías?" (102). Esa capacidad de reconocimiento se suma a otras cualidades que hacen de la locura de Susana un don especial. Nos referimos a su capacidad de visión y a su capacidad de invención verbal, que unos, como Barth, llaman poder poético, y otros, capacidad de permutación linguística.

Locura, visión y sueño no son temas nuevos en la literatura. Casandra, El Quijote, Hamlet, Hölderlin, Sade, lo atestiguan con creces. Susana ve y oye cosas que nadie más oye ni ve. Nos interesa de esa triple relación un bello problema que Rulfo deja sin resolver. Está planteado por tres escenas distribuidas en sendos fragmentos que ocurren quizá en tiempos distintos. En la primera escena, ocurrida una noche, Susana siente un "peso, en sus pies, caminando por la orilla de su cuerpo" (107), y cree ver en él a su padre. Escena seguida, entra Justina y le cuenta que Bartolomé ha muerto. "Entonces era él-y sonrió-. Viniste a despedirte de mí” (108). Luego, Susana recuerda su descenso al socavón de muertos. Abajo, al hallar el esqueleto, con el cráneo entre sus manos, enmudece de miedo. La calavera se deshace entre sus manos, y entonces

... ella no supo de ella, sino muchos días después entre el hielo, entre las miradas llenas de hielo de su padre (109).

He aquí el primer elemento del problema. Sabemos que la alusión a "muchos días después entre las miradas llenas de hielo de su padre" no se refiere a la noche en que ella tiene la visión de él viniendo a visitarla muerto, puesto que ella no le ve el rostro, sino al día en que Bartolomé le pregunta si está loca. El narrador introduce el segundo elemento del problema: Susana deja de recordar y suelta una carcajada. El narrador declara: "Por eso reía ahora” (109), y deja que Susana remate: "Supe que eras tú, Bartolomé” (109). 
¿Se refiere a que el peso, la sombra que había sentido la noche anterior era la de su padre agonizante? ¿O a que, en el descenso de niña, cuando halló la calavera, supo que aquellos despojos eran los futuros restos de su padre? "Entonces ella no supo de ella, sino muchos días después entre ... las miradas llenas de hielo de su padre": ¿no sabe de ella, la calavera?, ¿o no sabe de ella misma, Susana, porque se desmaya?, ¿o no sabe de ella, porque pierde la razón, porque enloquece, y el instante en que recupera la cordura es cuando su padre le dice que reconozca a Dios, a su madre y a él mismo y ella le confiesa que está loca, cobrando conciencia de su locura? Se nos antoja que el problema admite la triple respuesta. Susana posee un don superior de visión-ella no sueña, dirá enfáticamente-, al que llama locura. Al ver el cráneo descubre o intuye que es el de su padre, que será asesinado años después en la mina. Pero solo sabe de ese poco antes de que vaya a casa de Pedro Páramo y que su padre la obligue al reconocimiento. Ella llama locura a su don.

Como ejemplo de su segunda capacidad, la verbal expresada a través de las permutaciones del sentido, bástenos unos pocos ejemplos: Susana confunde al padre Rentería con su padre: "Ya sé que vienes a contarme que murió Florencio; pero eso ya lo sé. No te aflijas por los demás; no te apures por mí. Yo tengo guardado mi dolor en un lugar seguro" (111). La confusión de la palabra padre otorga sentidos distintos a la frase: dicha para referirse a Bartolomé, adquiere tintes de reconciliación y de suave confidencia; dicha para referirse al cura, de expreso reproche y rechazo sacramental. Sin embargo, el ejemplo más poderoso de cambio semántico lo hallamos en las escenas de la comunión y de la extremaunción. Cuando el padre Rentería la obliga a comulgar, "Susana San Juan, semidormida, estiró la lengua y se tragó la hostia. Después dijo: «Hemos pasado un rato muy feliz, Florencio»" (132). El cambio es doble: consumir el cuerpo de Cristo es rebajado a tragarse un fiambre y luego, en la imaginación de Susana, a consumir el cuerpo del amante. Otro muy distinto, y memorable, es el cambio producido en el responso que Susana agonizante da a la oración del cura:

-Tengo la boca llena de tierra.

[...] «Tengo la boca llena de ti, de tu boca. Tus labios apretados, duros como si mordieran oprimidos mis labios..". (135).

La escisión de "tierra" por "ti", que elimina el elemento de la pesadez -la tierra, el pecado- al que Susana ha vivido encadenada, hace aparecer la levedad del "ti", que es, a un tiempo, el otro y el amado. Parejamente, al vaciamiento corresponde una colmación, llenar la boca de algo, y una plenificación de ese algo como lo otro semejante: otra boca, tu boca; y es, parejamente, una repercusión del acto que se prolonga como consumo del amante-gemelo y de la palabra-gemela. Despojado de su trascendentalidad divina, el sacramento hace aparecer el ansia de trascendencia humana. La fusión de la 
llama doble, de que habla Paz. Esa fusión nos permite hablar de la última respuesta al padecimiento: el erotismo.

No podemos referirnos a él sin hablar de su cantidad cifrada, el cuerpo. La presencia física de Susana siempre está asociada a una serie de líneas delgadas construidas en parejas oposicionales (¿su propia tela ariádnica?) infranqueables a los demás: muerte-vida, recuerdo-sueño, luz-sombra, cubierta-descubierta, despierta-dormida, cuerda-loca. Susana las franquea sin obstáculo. En medio de muerte-vida, Susana es sobrevida, entre recuerdo y sueño es visión; entre luz y sombra, penumbra; entre despierta y dormida, duermevela; entre cuerda y loca, alucinada; entre cubierta y descubierta, desnuda. Por ello, en relación con los otros, el cuerpo de Susana es el lugar del límite, del ejercicio de la mirada y de la imaginación: es objeto de contemplación (¿qué otra cosa hace Pedro Páramo sino buscarla viva y muerta con los ojos?), de revisión y cuidado (por parte de Justina y del padre Rentería), y de imaginación (por parte de los vecinos, pendientes de la ventana "aluzada" de la Media Luna). Su cuerpo es la marca del ágon propio y ajeno: Pedro lucha con él hasta ser vencido por su clausura y su silencio; el padre Rentería es derrotado por su rechazo del cielo; el propio ágon de Susana culmina cuando su llama es sofocada por el dolor y la resequedad del amor.

El erotismo, medular en la historia de Susana, se manifiesta intensamente en los recuerdos del mar visitado junto a Florencio y en los últimos días de su vida. Cuando recibe la noticia de la muerte de su amante, la pasión contenida de Susana se desata:

[...] lo que yo quiero de él es su cuerpo. Desnudo y caliente de amor; hirviendo de deseos; estrujando el temblor de mis senos y de mis brazos. Mi cuerpo transparente suspendido del suyo. Mi cuerpo liviano sostenido y suelto a sus fuerzas. ¿Qué haré ahora con mis labios sin su boca para llenarlos? ¿Qué haré de mis adoloridos labios? (120).

El cuerpo es centro del dolor y la condena, pero también es presencia del deseo y posibilidad de salvación. Susana reprocha a Dios ocuparse de las almas y no del cuerpo, $y$, en tanto se libra al poder de la marca corporal de su amante, eleva el cuerpo ajeno y el propio a condición salvífica. "Mi cuerpo transparente suspendido del suyo. Mi cuerpo liviano sostenido y suelto a sus fuerzas" (120): su elegía es un himno al cuerpo que alivia el peso de la muerte, plenifica al otro y hace transparente la vida. Semejante lucidez se paga. Si Susana está atrapada en la esfera espantosa del mundo, también lo está en su cuerpo. Ha clausurado la palabra, pero no puede evitar que su cuerpo doliente sea también oyente, vidente, hablante. Convulsiones, sudor, risas, lamentos, manotazos, son todos signos de su expresión. No es casual, por tanto, que en sus últimas horas, esos signos se intensifiquen y en lugar de metáforas irrumpan las metonimias del sexo. Veamos dos fragmentos: 
Pedro Páramo abrió la puerta y se estuvo junto a ella [...]. Vio sus ojos apretados como cuando se siente un dolor interno; la boca humedecida, entreabierta, y las sábanas siendo recorridas por manos inconscientes hasta mostrar la desnudez de su cuerpo que comenzó a retorcerse en convulsiones (131).

En la veintena de veces que la palabra boca aparece en la novela-relacionada con la voz, con el infierno, con el alma-, pocas le dan una carga erótica como las que refieren a Susana: "su boca y sus ojos 'como de dulce"”; "boca humedecida, entreabierta"; "Tengo la boca llena de ti". En el framento examinado, la alusión a la boca está en relación con la tensión corporal y la desnudez y prepara con sutileza la expresión directa del vientre.

Susana San Juan estaba incorporada sobre sus almohadas. Los ojos inquietos, mirando hacia todos lados. Las manos sobre el vientre, prendidas a su vientre como una concha protectora (130).

La imagen venusina es sancionada por la moral. Por el cuerpo (el vientre) entró el pecado al mundo (la muerte). Resultan iluminadoras las manos de Susana sobre el vientre: protegiéndolo, dice Rulfo; aferrándose a él, añadimos nosotros, movidos por la idea de que de todos las partes de su cuerpo que aún preservan vida-el oído le es infiel, los ojos le fallan-, el vientre es el último rincón al que puede asirse para no terminar de caer. Aunque intuye también que ello ya no es posible. La muerte se le arroja encima y ella no puede responder más que con su autodevoración, con el gesto urobórico que cierra su historia:

Después sintió que la cabeza se le clavaba en el vientre. Trató de separar el vientre de su cabeza; de hacer a un lado aquel vientre que le apretaba los ojos y le cortaba la respiración; pero cada vez se volcaba más como si se hundiera en la noche (137).

\section{III}

\section{Los signos de la trascendencia}

Obremos en esta parte final por contrapunto y consideremos los signos de la trascendencia presentes en las dos obras. Tales signos son: el valor del instante, los sueños y la construcción y destrucción de lo divino. Empecemos con el tiempo, que en ambas obras se traduce como la revaloración del instante. Se advierte en ambas el esfuerzo, extensible al barroco, de la prolongación adrede del instante-que De Campos ha llamado la diferencia (Campos, De la razón antropofágica: Europa bajo el signo de la devoración, 1999)- entendiendo que traza un sentido, una orientación distinta, y que difiere la producción plena del sentido. ¿Cómo se da tal diferencia? Tomemos los 
primeros versos de Primero sueño y la secuencia del descenso de Susana al socavón de muertos: 24 versos iniciales de Primero sueño constituyen un solo párrafo, y poco más de 40 líneas conforman la escena de Susana.

Para Waldo Ross (1972) el párrafo inicial de Primero sueño construye la idea del tiempo paralizante de la noche. En términos dramatúrgicos, la voz poética ha dispuesto el espacio-tiempo y la escenografía total que llevan al inicio del viaje y del ascenso: los movimientos siderales, el cono piramidal, la lucha de la sombra y la luz, la luna imperiosa que impone silencio y la fauna nocturna. El sentido ha sido, en efecto, postergado por dos operaciones internas: la elongación del párrafo y el hipérbaton: “...de la tierra /nacida sombra al Cielo encaminaba /de vanos obeliscos punta altiva /escalar pretendiendo las Estrellas". El metalenguaje del viaje se expresa en el escalar, y este a su vez, en la dificultad para abordar cada escalón. El poema impone de entrada su ritmo y concepción del espacio tiempo: ritmo lento, dificultuoso como el espacio-la escala-, y tiempo moroso que poco a poco nos dona su sentido. Pero no debemos olvidar que se trata de exponer un solo instante (el rapto del sueño) y asimismo toda la maquinaria del instante. Se trata de destruir la sucesión temporal.

Para ello, el poema debe postular nudos de instantes. Todo el primer párrafo obra, de modo lato, como una bisagra semántica. Aquí, abre con los preliminares del sueño; habrá que esperar casi cien versos para que aparezca otro nudo, cerrándola: "El sueño todo, en fin, lo poseía; /todo, en fin, el silencio lo ocupaba" (147). Ese "en fin" representa el ya no y el aún no propios del instante. El instante representa no sólo cada uno de los momentos del poema, sino que anudando otros instantes teje la totalidad del poema mismo: para citar los versos de Sor Juana, funciona como "compendio misterioso", como una "bisagra engazadora" (659).

Operación semejante se halla en el descenso de Susana. La secuencia está constituida por tres escenas: la visita de Bartolomé, la noticia de su muerte y el recuerdo del descenso. Bartolomé muerto visita a Susana el domingo a medianoche, la noticia de su muerte llega el día lunes a la mañana. Este lunes, Susana recuerda su descenso al socavón. El tiempo verbal del recuerdo arranca con el pluscuamperfecto ("Había entrado por un pequeño agujero") y luego pasa a pretérito simple ("Y ella bajó y bajó en columpio") que por medio de elipsis se va volviendo más y más puntilloso ("Le fue dando pedazo a pedazo", "y le entregó coyuntura tras coyuntura...”) hasta detenerse en la parálisis de miedo de Susana y en su posible desmayo: "Entonces ella no supo de ella...".

Aquí, la forma no es la gradación sino una figura consubstancial a la escena: el círculo o, para mayor precisión, la espiral. El tiempo amplio de la noche se concentra en la mañana y se intensifica en el socavón. La calidad del tiempo-espacio y de la escenografía varía de escena a escena: en las dos primeras, el tiempo atmosférico es claro: medianoche, mañana gris; el espacio es definido: cuarto de Susana; pero la escenografía es borrosa, fantasmal. En la escena del socavón el tiempo es impreciso: desconocemos 
la hora del día; el espacio, borroso, es iluminado a flecos por el haz de la linterna; pero la escenografía es de intensidad furiosa. Luz y espiral descendente precipitan así el tiempo y lo paralizan en el instante.

Lyotard (1998) ha hablado del instante como tiempo condensado, como un relámpago en que el poeta construye el vacío, ese vaciarse fundamental entre lo que ya no es y lo que aún no ha sido, de forma que dé lugar a la presencia por medio de la cual el mundo "no deja de comenzar". El poeta inmoviliza el mundo y el poema con la idea de devolverlo al punto cero de la creación: el segundo que separa el dedo de Dios de la nada y del Big Bang. Al comienzo de estas páginas hablamos de la aspiración del poeta a un lugar sobrenatural donde le sea dado ver el libro de Dios. Aquí apuntamos radicalmente que el poeta no sólo desea ocupar ese lugar sino sustituir a Dios. Y en ese mismo acto ocurre la respuesta sobre el ser del poeta en tanto creador. El instante es la afirmación, siquiera fugaz, del ser y de la derrota del tiempo y de la muerte por parte del poeta.

Una relación final que nos interesa es la que se da entre instante y metáfora. Ricoeur (2001) ha postulado la naturaleza semántica de la metáfora como identidad, no identidad y analogía. El instante se concibe, en primera medida, como identidad, pues es lo que se presenta entre un ya no y un aún no; en segunda medida, como no identidad, porque asemejándose al presente, no es lo que pasa sino lo que se presenta. El instante es presencia. El instante, la presencia, relampaguea no en forma de elevación-categoría por la cual Aristóteles distingue la tragedia-, sino de intensificación. Y para ello requiere de la paralización de lo contado, del caos. La cercanía entre el instante y la metáfora se colma en la operación semántica central, la analogía: como si. La dilatación del sentido del instante cobra aquí valor de plenitud: el instante es como si el mundo volviera a ser creado, semejante a una promesa de eternidad, a tallar en la punta del rayo la gema palpitante de la vida.

El segundo signo de trascendencia es el sueño. En su estudio sobre la obra de Sor Juana Inés, Susana Arroyo Hidalgo (2001) afirma que el uso de la palabra sueño se refiere a "la expresión de la actividad mental que vive en nosotros, que piensa, que siente, que especula por nuestras vivencias diurnas". El término puede ser extensivo a la actividad de Susana en la obra de Rulfo. Ahora bien, en una y otra obra, esa actividad cobra gradualmente un sentido distinto. Va del acto físico de descansar y dormir a la fantasía y la ensoñación, y de aquí al sueño premonitorio, visionario. El sueño como saturación semántica.

Pascual Buxó indica que "Sor Juana hizo una admirable síntesis lírica de las teorías aristotélicas y postaristotélicas del sueño y los ensueños, de manera que en poco menos de 150 versos (145-291) quedaron cifradas en su poema todas aquellas nociones fisiológicas y psicológicas susceptibles de dar una explicación científica de las causas del dormir y del soñar" (Buxó, 1984). Lo que no señala Buxó es la saturación semántica a que aludimos. 
El sueño de Sor Juana Inés trasciende el rapto místico hacia una experiencia personal de conocimiento. Sin guías ni maestros, ella viaja sola, hundiéndose en el sueño lúcido, acto político por rebeldía. Resultado de ello, sus ojos se llenan de luz. Yo despierta es la divisa de su libertad. Como en muy pocas obras -Dante y Borges-Primero Sueño nos lleva a tomar conciencia de un hecho crucial: en su poderoso desorden, el sueño es un espejo de la vida que se nos arroja encima en un desorden similar. Tendemos a ver la vida en la organización fugaz que le da la razón, en una triple apariencia de esencia, de secuencia, de consecuencia; pero el sueño nos permite verla como es: caos, instante, presencia. He ahí su relación con la poesía. Sueño y poesía son una inversión de la mirada: desocultación, revelación. Nos precipitamos en el sueño, como en la poesía, para ver la vida cara a cara, desde afuera.

Susana, igualmente, se refugia en el sueño por rebeldía, como acto político. Vecinos y allegados la ven o la imaginan "desnuda y dormida" en su lecho de enferma. Pedro, Justina y el padre Rentería la ven revolverse en sueños terribles. Ahora bien, ella afirma no soñar. Entonces, ¿qué tipo de sueño es el suyo? ¿Alucinación, ensueño, visión, pesadilla? Hay algunas pistas: dormida, Susana parece vivir una ensoñación plácida, poblada de erotismo y deseo. El narrador aclara:

Esa noche volvieron a sucederse los sueños. ¿Por qué ese recordar intenso de tantas cosas? ¿Por qué no simplemente la muerte y no esa música tierna del pasado? (120).

El narrador aclara que Susana tiene sueños. Enfatiza que están conformados de recuerdos intensos. Y, acto seguido, en una muda sutilísima, se hace conciencia del personaje y desea la muerte en lugar de esos recuerdos y de "esa música tierna del pasado".

Pedro Páramo va a recordarla siempre como la que duerme. Para él, los sueños de Susana son exilio y refugio: huye de su amor y se refugia en un mundo que es imagen de la muerte. Mortificado por esa idea, Pedro termina viéndola como muerta. La que duerme es la que muere. Hemos dicho páginas atrás que Susana teje un laberinto de piedra para Pedro Páramo. Ahora podemos enunciarlo como sigue: al condenarlo a mirarla dormir, a intuir sus sueños, Susana lo obliga a convertirla en recuerdo. El infierno del amante es no poder ver al objeto amado directamente sino bajo forma de nostalgia. Susana es la Gorgona. Pedro se petrifica.

[...] Había una luna grande en medio del mundo. Se me perdían los ojos mirándote. Los rayos de la luna filtrándose sobre tu cara. No me cansaba de ver esa aparición que eras tú. Suave, restregada de luna; tu boca abullonada, humedecida, irisada de estrellas; tu cuerpo transparentándose en el agua de la noche. Susana, Susana San Juan (146-147). 
Pedro Páramo mira a la dormida, a la muerta, a la recordada, hasta demudarla en una diosa lunar de la que sólo queda un nombre con resonancia de eses, de enes y de vocales como ondas de una piedra hundida en el agua de la noche. En el sueño, Susana escapa del poder de Pedro Páramo y se une al recuerdo del amor. Ella dormida sintetiza la conquista de un reino de libertad precaria, pero también una forma de condenar a quienes la condenaron. Así como los ojos de Sor Juana se llenan de luz, la boca de Susana se llena de amor. Ambas se llenan de poesía.

¿Cómo remata y se intensifica el sueño en ambas obras? La respuesta tiene que ver, primero, con los dos sintagmas verbales yo despierta y ella dormida y, segundo, con la enunciación y la identidad: en Primero sueño hay un enunciador que se identifica con la persona gramatical yo que construye una doble identidad: un yo que envía al hablante poético y un yo que envía a la autora. Esa carga identitaria imprime a la experiencia del sueño una intensidad enorme, tanto más si se tiene en cuenta que la operación del soñador es la del progresivo ocultamiento del yo mediante la exposición objetiva del viaje. Sólo despunta en los versos 617-618: "De esta serie seguir mi entendimiento / el método quería", para volver a ocultarse y despuntar sorpresiva y brillantemente en el último verso: "el Mundo iluminado y yo despierta" (975). En el ápice del sueño, del poema y del rayo, destella el instante del yo.

En el caso de Susana, la enunciación ocurre de dos maneras. Existe un enunciador identificado con la persona gramatical yo, que envía a Susana; y hay un segundo enunciador identificado con la persona gramatical él que envía a una tecera persona que observa a Susana (el narrador, Justina, Pedro Páramo) y que se resume en el sintagma Ella dormida. El primer enunciador, Susana, construye una intensificación argumental del yo enmarcada por la pregunta "¿Y yo quién soy?". Podemos resumir la historia de Susana en cuatro argumentos tomados de toda la novela, para que el lector capte la gravedad de lo dicho: a) "Yo no sueño nunca" (106); b) "Yo tengo guardado mi dolor en un lugar seguro" (111); c) "Lo que yo quiero de él es su cuerpo" (120); d) "Yo sólo creo en el infierno" (131). La segunda intensificación es imaginal y está asegurada por el enunciador en tercera persona. Ya hemos señalado la potencia de la imagen de Susana contemplada mientras duerme. Pedro Páramo resume la intensidad demoledora de esa imagen. Pero esta sólo logra su expresión plena con la creación de una segunda mirada cómplice: la del enunciatario. Entre él y ella aparece un tú: el lector. La historia de Susana debe su intensidad a que vemos a la durmiente desde afuera; a que nos hemos asomado al torbellino de su alma; y a que, quizá por una vez, creemos comprender ese misterio que nos asalta al ver dormir al otro, al muerto, al ser amado.

Podemos tomar como ejemplos la pregunta inicial, ¿Y quién soy yo?, y los cuatro argumentos de Susana para referirnos al último signo de la trascendencia: la construcción y destrucción de lo divino. Según Víctor Bravo (1998), María Zambrano ha sancionado el surgimiento de los dioses como invención humana, nacido de una matriz esencial 
que mueve al hombre a la trascendencia y que lo convierte en "el único animal que mira al cielo". Pero surge entre el hombre y los dioses un abismo insalvable allanado únicamente por el sacrificio. "Solo una religión del amor hará accesible a los dioses, y eso sólo es posible en la inversión del sacrificio: del sacrificio del hombre al sacrificio de Dios. Pero esa inversión producirá la destrucción de lo divino" (Bravo, 1998).

Entre las formas de la destrucción, María Zambrano sitúa a la pregunta. Job discute con Dios, y la pregunta hace aparecer el poder de la conciencia. El quién soy yo de Susana y su cuádruple argumento configuran la radicalización de una conciencia que apuesta por: a) la locura, b) el padecimiento, c) el amor, d) la condenación. Esta condenación se intensifica, a su vez, en la expresión de Bartolomé: "Tu madre decía que cuando menos nos queda la caridad de Dios. Y tú la niegas, Susana" (102); en la del padre Rentería: "Quizá ella no tenía nada de que arrepentirse" (136); y por boca de Susana:

¡Señor, tú no existes! Te pedí tu protección para él. Que me lo cuidaras. Eso te pedí. Pero tú te ocupas nada más de las almas (120).

Dios es proscrito. Ha sido reemplazado por una fe en el cuerpo concreto, sufriente, amante, y por la consecuente sacralización de ese cuerpo. Susana ha consumido el cuerpo de Cristo y lo devuelve transfigurado en la carne:

...lo que yo quiero de él es su cuerpo. Desnudo y caliente de amor; hirviendo de deseos; estrujando el temblor de mis senos y de mis brazos. Mi cuerpo transparente suspendido del suyo (120).

El padre Rentería quiere librar un último combate: "Vas a ir a la presencia de Dios. Y su juicio es inhumano para los pecadores". Pero Susana lo desarma con un argumento que prueba su ajuste de cuentas con su conciencia:

¡Ya váyase, padre! No se mortifique por mí. Estoy tranquila y tengo mucho sueño (137).

Rulfo no opta por el camino del cielo y no se detiene en la producción imaginativa y punitiva del infierno. Arrancando de la condición mítico-religiosa americana, del no-lugar, de la indefinición ontológica, del espacio vacío, del despojamiento, se detiene en la imagen del Purgatorio ${ }^{4}$. Contra la oscuridad, el dolor, la sequedad y la nostalgia terrible que recorren su mundo de muertos, la conciencia luminosa, el erotismo desatado y la locura sacralizada de Susana se imponen como un aligeramiento, una posibilidad

4. Tras la conquista, los indios y mestizos mexicanos dieron a la condición de no-lugar el nombre de nepantla, término náhuatl que designaba el vivir atrapado entre dos culturas, mundos y caminos; el espacio liminal e indeterminado en el cual solo era posible la auto transformación. Esa idea es la que Rulfo hace cristalizar en su imagen del Purgatorio. 
de fuga y de redención humana de la condena. Rulfo alcanza la brevedad, el poder y el secreto de la poesía a través de "esas hilachas colgando", como llama a los fragmentos de Pedro Páramo, rompiendo la estructura de la novela y perfeccionando el arte de tachar. $\mathrm{Y}$, de paso, construye para América una condición poética diferente, en el sentido que da De Campos al término, pero también diferente a una escritura europea, una escritura profundamente americana.

Monumental, mental, sólida, la pirámide que erige Sor Juana es una metáfora del logos auto devorador. Una aventura de la palabra contra sí misma. ¿Qué queda de ese choque de intuición y razón, de noche y día, de materia y espíritu, de tiempo y finitud, de palabra y Palabra? Quedan dos cosas: derrota y poesía. Octavio Paz (1982) va a afirmar que ante la contemplación de la máquina espantosa del universo, el intelecto ve pero el entendimiento no es capaz de comprender. Impulsada por éste, el alma retrocede, "da las espaldas el entendimiento, /y asombrado el discurso se espeluza /del difícil certamen que rehúsa /acometer valiente, /porque teme-cobarde- /comprehenderlo o mal, o nunca, o tarde..." (764-769).

La máquina del universo aplasta parejamente intuición y ciencia. La semilla divina sembrada en el hombre no ve la luz. El hombre, en su doble tentativa, acusa la derrota. Sin embargo, el poema no plantea con esta la única derrota de lo divino ni la derrota definitiva de lo humano. Antes bien, la derrota de lo primero supone el triunfo de lo segundo. Y ello ocurre gracias al erotismo. Sor Juana logra que el erotismo atraviese el poema (recordemos su expresión más vívida en el episodio de la Flor Carnal: "dulce herida de la cipria diosa", que corre de modo parejo al curso filosófico del poema. Mediante el discurso doble característico del barroco, Sor Juana construye un gesto total que ha avanzado de lo filosófico a lo erótico, como se ha visto, pero que se remonta aún más allá, a la esfera de lo político.

Arroyo Hidalgo (2001), citando a Leiva, señala cómo el pasaje refleja el espíritu humanístico de Sor Juana y "hace referencia a la amorosa unión como confesión de un drama pasional ya que, para Leiva, a lo largo del poema se vislumbra una imantación amorosa que Sor Juana tuvo que esconder para no ser el blanco de envidias y persecuciones". La constatación del secreto flujo erótico del poema puede ser suficiente para oponerlo a la divinidad. Pero no. Creemos que lo erótico aquí no sólo está puesto como un discurso subterráneo sino que hace referencia al conocimiento oculto al que la divinidad no tiene acceso. "Ya vieron tus ojos mis obras siendo escritas todas en tu libro", señala el salmo bíblico que abre estas páginas; pero también hay otro pasaje sagrado que confiesa: "Tres cosas hay que me son maravillosas y una cuarta que no consigo comprender: el rastro del águila en el cielo, el rastro de la nave en el mar, el rastro de la serpiente en la roca y el rastro del hombre en la mujer". (Proverbios 30:18). Dios comprende los secretos del mundo, salvo uno, el del amor. Tal confesión es conmovedora por un motivo teológico, "porque si tal como sugiere Ernesto Sábato, la Biblia es la primera obra abierta en la 
que Dios es autor y protagonista a la vez, Dios hace aquí confesión de ignorancia en torno al misterio del amor: no consigo comprender. Ya podemos imaginar el escándalo teológico que deriva de semejante desliz divino" (Delgado, 2002).

Lo profundamente político del gesto de Sor Juana se da, pues, en oposición al discurso religioso y a la institución eclesial, en la conjugación de una triple aventura: de conocimiento total (aventura epistemológica, según Sabat de Rivers), erótica y libertaria. Todo ello potenciado por su compleja condición de mujer, de monja, de ser pensante, de sintiente y de poeta.

Esta última condición es decisiva. Como Dante, Sor Juana se remonta en busca del conocimiento. Luego de su doble fracaso, el Primero sueño la deja en la orilla opuesta de la sombra, la poesía. Tras la búsqueda del logos supremo, a Sor Juana la aguarda la poesía, como su premio y su sueldo. Parece cosa inane y, sin embargo, sus descripciones del Hombre, la metáfora de la Flor Carnal, el episodio final del poema, profundamente líricos, y ese cierre de altísimo magisterio no son ni menores ni menos significativos que todo el rapto abstraccionista del viaje. Señalan el triunfo del rapto tonal de la poesía. Yo despierta es un reconocimiento de la lucidez y de la vida, de la existencia transformada por la poesía; el hallazgo del destino.

En ese sentido, Primero sueño puede ser leído como fundamento del pensamiento poético y de la razón poética que se funden en una condición humana más intensa, la poética. Sor Juana, hemos dicho, recoge el impulso del Renacimiento y del Siglo de Oro. En sus manos, ese impulso sufre trasformaciones significativas que nos permiten hablar de una condición poética distinta. Con Primero sueño, Sor Juana funda para América tal condición. Una condición superior: de ahí primero entendido como fundamental; de ahí el sueño, como vehículo de la libertad ontológica; de ahí el poema, como otra forma de conocimiento y como empresa superior del ser humano.

\section{A modo de conclusión}

Cedomil Goic, en Góngora y la retórica manierista de la dificultad docta (1961), habla de "la condición particular, extraña al uso, de la condición poética hasta hacerla lengua de pocos y animarla de un excepcional espíritu de secta". No nos mueve una reflexión que promueva tal espíritu. Antes, lo contrario: creemos en las potencialidades de reflexión que permitan la comprensión de ese espíritu como una posibilidad humana amplia y democrática, no restrictiva de la poesía.

En esa vía, acogemos la idea de incorporar a la crítica en tal propósito. La manera como la crítica puede contribuir a la condición poética se da en la posibilidad de constituirse creativa. Una crítica creativa, como lo sostiene Noé Jitrik (2014), que provee no solo un arsenal conceptual y metodológico sino que hace una apuesta para elevarse a 
una actividad de significación alta y perturbadora tal como la hicieron Borges o Reyes, es quizá una de las vías para fortalecer el legado que el siglo xx nos dejó.

Ello, sin olvidar que esa vía ya fue trazada por los mismos creadores y poetas que vieron la necesidad de distanciar sus enfoques de los del resto del mundo, construyendo nuevas orillas y metáforas: Sor Juana discutiendo con Góngora y el romanticismo alemán; Rulfo respondiendo a la metáfora dantesca; Borges reconstruyendo la tradición occidental desde el fantástico, la parodia, la ironía y la inteligencia desmesurada; García Márquez, refundiendo los conceptos europeos que constituyen la realidad, y devolviéndolos en metáfora potente, recombinada, de una nueva realidad.

\section{Referencias}

ALAZRAKI, J. (1968). La prosa narrativa de Jorge Luis Borges. Madrid: Gredos.

ALAZRAKI, J. (1971). Jorge Luis Borges (Columbia Essays on Modern Writers). New York: Columbia. ARISTÓteles, HORACIO Y BOILEAU. (1982). Poéticas. (A. G. Pérez, Ed.) Madrid.

ARROYO HIDALGO, S. (2001). Una lectura de "Primero sueño", de Sor Juana Inés de la Cruz. Universidad Nacional Autónoma de México, Humanidades. México: UNAM.

BARTH, J. (1967). La literatura del agotamiento. The Atlantic Monthly, 220 (2).

BLOOM, H. (2001). El canon occidental. Barcelona: Anagrama.

BORGES, J. L. (1973). Ficciones. Caracas: Ayacucho.

BORGES, J. L. (1982). Nueve ensayos dantescos. Madrid: Espasa.

BORGES Y SÁBATO. (1996). Diálogos. Buenos Aires: Emecé.

BRAVO, V. (1998). De padecer y la trascendencia. La filosofía poética de María Zambrano. (U. C. Madrid, Editor) Recuperado el 30 de Marzo de 2015, de Espéculo. Revista de estudios literarios: http:// www.ucm.es/info/especulo/numero1o/zambrano.html

BUXÓ, J. P. (1984). Sor Juana Inés de la Cruz en el conocimiento de su sueño. En C. d. Humanidades (Ed.), Discurso. José H. Moreno de Alba, Contestación. México: UNAM.

CAMPOS, H. D. (S.F de s.f.). De la razón antropofágica: Europa bajo el signo de la devoración. La Torre, $235-258$.

CRUZ, SOR JUANA INÉS DE LA (1976). Obras completas de Sor Juana Inés de la Cruz. Tomo I. Lírica personal. Edición crítica de Alfonso Méndez Plancarte. (1951). Biblioteca Americana. México: FCE. 
SAGRADA BIBLIA. Salmos, 139:16. (1966). (N. Colunga, Trad.) Madrid: Editorial Católica. De Toro, A. (1995). Postcolonialidad y postmodernidad. Jorge Luis Borges o La periferia en el centro/ la periferia como centro/ el centro de la periferia. Iberoromania (44), 64-98.

DE TORO, A. (1992). El productor 'rizomórfico' y el lector como detective literario: la aventura de los signos o la postmodernidad del discurso borgesiano (intertextualidad-palimpsesto-rizoma-deconstrucción). En A. De Toro, \& K. A. Blüher, Jorge Luis Borges: procedimientos literarios y bases epistemológicas (págs. 145-184). Frankfurt am Main: Vervuert.

DE TORO, F. (2002). Intersecciones II: ensayos sobre cultura y literatura en la condición posmoderna y poscolonial. Buenos Aires: Galerna.

DELGADO, H. (2009). Novela y metáfora,. Tensionesy extensiones. Universidad del Valle, Humanidades. Cali: Universidad del Valle.

DELGADO, H. (2002). Atributos de la poesía. Clave.

GOIC, C. (1961). Góngora y la retórica manierista de la dificultad docta. Atenea, CXLII(393), 169.

GONZÁLEZ ECHAVARRÍA, R. (1986). Borges y Derrida. Letras de Buenos Aires. (16), 9-21.

GUSDORF, G. (1991). Condiciones y límites de la autobiografía. Suplementos Anthropos $N^{o}$ 29, 9-18.

JAY, M. (2009). Cantos de experiencia.Variaciones modernas sobre un tema universal. Buenos Aires, Argentina: Paidós.

JITRIK, N. (2014). Enfoques Críticos. Algo de literatura latinoamericana en su-gestión. Pereira.

JITRIK, N. (2014). Productividad de la crítica. Lección inaugural del Doctorado en Literatura, 22. Pereira: Universidad Tecnológica de Pereira.

LYOTARD, J.-F. (1998). Lo inhumano. Charlas sobre el tiempo. Buenos Aires: Manantial.

MIGNOLO, W. (1987). Diálogo y conversación. En Diálogos hispánicos de Amsterdam, N 6. La semiótica del diálogo. (págs. 3-26). Amsterdam, Mignolo, Walter. Amsterdam: Rodopi B.V.

MORALES ORTIZ, G. M. (1999). La trayectoria intelectual de Antonio Cornejo Polar. Revista de Crítica Literaria Latinoamericana(25), 187-197.

PAZ, O. (1982). Sor Juana Inés de la Cruz o las trampas de la fe. Barcelona: Seix Barral.

RICOEUR, P. (2001). La metáfora viva. España: Trotta-Cristiandad.

ROSS, W. (enero-marzo de 1972). Las Maha-Vidya-s y el Sueño de Sor Juana . Revista de la Universidad de Antoquia(184), 81-99.

RULFO, J. (1988). Pedro Páramo - El llano en llamas. Madrid: Aguilar.

SABAT DE RIVERS, G. (s.f.). Sor Juana y su Sueño: antecedentes científicos en la poesía española del Siglo de Oro. Cuadernos Hispanoamericanos, 310, 186-204.

VALÈRY, P. (1998). Teoría poética y estética. Madrir: Visor. 